\title{
Old Obligations in the Modern World: The Father as Provider before and after Divorce
}

\author{
RADKA DUDOVÁ* \\ Institute of Sociology AS CR, Université Paris 5 - René Descartes
}

\begin{abstract}
The article draws on empirical qualitative research to identify the various ways in which separated or divorced fathers in the Czech Republic relate to the norm of father-provider. It offers an analysis of the plurality of men's approaches to the traditional provider norm of fatherhood, and the changes that occur in their attitudes and approaches as a result of divorce. The results show that although for Czech men the 'provider' dimension is the strongest dimension in their notion of fatherhood even after marital separation, their understanding of what material support for the children means is transformed by the fact of separation. In the father's view, the child, along with the family, ceases to be a joint enterprise, and the child often becomes identified with the ex-wife. According to their notions and practices concerning child support, the men in this study can be divided into three groups: nurturing fathers who reject the provider/caregiver division and thus refuse to pay; helping fathers who consider their children to be primarily the ex-wife's responsibility, and thus only pay small amounts of money, and the fathers-providers who are willing to fully support their children, but only if this support is voluntary and under their control.
\end{abstract}

Keywords: parenthood, fatherhood, marital separation, child support, family Sociologický časopis/Czech Sociological Review, 2006, Vol. 42, No. 3: 573-590

The vast majority of social-scientific research dealing with the issue of parenthood after divorce focuses mainly on examining the impact that divorce has on the children and on analysing the situation of mothers who have sole custody of the children, while fathers are most often considered in terms of an intervening factor. Contemporary research on fatherhood has yet to take up the task of revealing how men, after divorce, cope with the loss of everyday contact with their children, how they re-define their fatherhood, and what changes their paternal role, their identity, and the way they care for their children undergo. To this end it is also necessary to investigate the ways in which fathers handle the varied and sometimes even incompatible standards that nowadays apply to fatherhood, and how they reconcile the discrepancies that exist between the old, traditional normative demands and the

\footnotetext{
* Direct all correspondence to: Radka Dudová, Institute of Sociology AS CR, Jilská 1, 11000 Prague 1, Czech Republic, e-mail: Radka.Dudova@soc.cas.cz
}

(C) Sociologický ústav AV ČR, Praha 2006 
new, modern ${ }^{1}$ normative demands. In the traditional normative model of fatherhood the father is first of all the provider, responsible for ensuring the material comfort of his children. Sociological studies show that in the Czech Republic this is still a very significant dimension of fatherhood, even though the specific substance of the dimension is changing. Moreover, it is predominantly assumed that when a couple who are parents divorce the father continues to be the provider for his children, and this dimension of fatherhood persists even beyond the fundamental changes that other dimensions have already undergone.

In this paper the author draws on empirical qualitative research to identify the various ways in which separated or divorced fathers in the Czech Republic relate to the norm of father-provider, how they interpret it subjectively, and in what way this norm is reflected in their behaviour. The article goes on to analyse the plurality of men's approaches to the traditional provider norm of fatherhood, and the changes that occur in their attitudes and approaches as a result of divorce. The objective of the article is to discover some of the reasons why, after divorce, only a limited number of fathers fully attend to their court-ordered duty to provide their children with economic support. ${ }^{2}$

\section{The paternal role}

In order to obtain an accurate grasp of the problem it is first necessary to clarify the theoretical conception of social roles in general and the paternal role in particular. Social roles are traditionally defined as the expected manner of behaviour that is tied to any particular social status [Velký sociologický slovnik 1996: 943]. The paternal role may be understood as referring to the sum of everything that is expected from the person who occupies the status of father, that is, the entire inventory of norms associated with the social position of 'father'. The way in which a man plays his pa-

\footnotetext{
${ }^{1}$ I use these terms in their common-sense lexical meaning, not in the sociological sense. In this sense 'tradition' means a long-term custom or practice. The 'traditional' norm of fatherhood corresponds to the traditional and the first phase modern society, while the development of the 'modern' norm of fatherhood corresponds to the second phase of modern society (since the 1960s) (see Singly [2000: 16]). 'Traditional' therefore refers to the norms and obligations that were most strongly associated with fatherhood during the first industrialisation period, when the workplace and the home were separated and fathers began to be absent from the home for longer periods during the day.

${ }^{2}$ Data on the degree of compliance among divorced fathers with court-ordered child support payments are unfortunately not yet available in the Czech Republic. It may be assumed that the rate of compliance will correspond to that observed in other countries: the American authors D. R. Meyer and J. Bartfield [1996] assert that 15\% of fathers pay nothing, $41 \%$ pay part of the sum they are required to pay, and $44 \%$ pay the full amount; the Canadian author M. Baker [1997] cites national estimates indicating that $50 \%$ to $75 \%$ of fathers pay nothing or only part of what they are required to pay.
} 
ternal role depends on the hierarchical order in which the individual dimensions are arranged, and after a divorce for many reasons this hierarchy often changes.

The classic definition of a social role no longer corresponds to social reality today. More appropriate appears to be the French sociologist Francois de Singly's concept of roles and identity [2003: 99-100], according to which nowadays there is no single role that corresponds to a given social position - although this has been the traditional view in the social sciences - and instead individuals construct numerous personal roles on the basis of various registers or social repertoires. Repertoires are 'narratives in which only one of the dimensions pertaining to the role figures' [Singly 2003:100]; they are particular patterns of behaviour that all individuals in a given social position have available to them and which they choose from and combine to create their own version of a particular role. This means that it is possible to identify multiple, different repertoires pertaining to the social position of the father and associated with each particular dimension of fatherhood. The actors choose from and combine these repertoires to create their own paternal role. In this way they select their own personal way of being a father, and this personal role becomes part of their identity (for more on the notion of roles and identity see Singly [2003]). To study the nature that the paternal role acquires after parents divorce, it is necessary to reveal how individuals construct their roles on the basis of various repertoires and to examine the kinds of relationships that exist between these individual repertoires.

\section{The traditional and the modern norm of fatherhood}

It is possible to trace some common features in the various theoretical approaches to contemporary fatherhood [Ihinger-Tallman, Pasley and Buehler 1995; Singly 2000; Modak and Pallazo 2002] and to distinguish two basic groups of norms - for simplification they are referred to here as the traditional and the modern norms of fatherhood (see footnote 1). The traditional norm involves the functions of intergenerational transmission and authority and especially the father's obligation to materially provide for the family, while the new, modern norm expects emotional closeness, the father's physical presence, and his active involvement in looking after the children and, in some cases, also the household. While traditionally the father was a father 'by proxy', i.e. his parental role was to a large extent mediated by the mother, partly by the way in which she spoke of him to the child, and partly by how she spoke about the child to the father, the modern father is meant to have a direct, unmediated, and personalised relationship. Evidence of the effect of the modern norm of fatherhood can be found in some trends in contemporary social policy, for example, the introduction of parental leave and the ongoing discussion over short-term paternity leave, which would enable a father to spend at least several days with his newborn child.

Data from quantitative surveys conducted over the past ten years (ISSP 1994; Naše společnost/Our Society 2003) indicate that in Czech society the traditional norm 
of fatherhood is still quite strong. Even though women have been active in the labour market now for several generations, the ideal notion maintained by a full one-half of all Czech men and women about the arrangement of roles in the family is still very traditional in character: the man is supposed to see to the family's financial security and the woman is primarily responsible for looking after the children and the household [Hašková 2003: 39; Radimská 2003: 12]. Even though the family budgets of the majority of households require both parents to be economically active in order to maintain a satisfactory standard of living, and even though women are considered 'co-providers', according to $90 \%$ of Czech men and women it is still the main task of the father to provide as best as possible for the financial security of his family [Naše společnost/Our Society 2003]. These data illustrate the specific situation the Czech Republic is in as a transition country still affected by the legacy of communism, in which modern elements (a high percentage of women in the labour market, a well-developed system of institutional childcare to help reconcile work and family responsibilities, a high divorce rate) and traditional elements (vertical and horizontal gender segregation in the labour market, persistent gender stereotypes in the family) were combined. Modernisation was moreover largely and artificially enforced and was not accepted or viewed as positive by large segments of the population.

What does this division of roles mean in terms of being a parent? Outside the father's economic responsibility there is no specific sphere of raising or caring for the children where he is engaged more than the mother. The woman is responsible for the majority of activities connected with parenthood, and if the father's involvement increases, then it does so only alongside the mother, either with her or in her place when she is unavailable [Singly 2000: 182]. If the parents divorce, the mother ceases to represent the parental couple in her relationship with the children, and the father's absence consequently acquires a new significance. Before, though he may not have been personally present in the family for the majority of the time, his presence was mediated through the mother. After a divorce he becomes genuinely absent, even if in the end he is spending as much time with his children as he spent before [see also Bowmann and Ahrons 1985].

Below we will look at the results of a qualitative study of divorced fathers in the Czech Republic ${ }^{3}$ and see how Czech fathers define themselves in the face of the traditional norm of fatherhood and what kind of influence the provider repertoire has on their individualised paternal role. We will look at how the use of this repertoire changes after the marriage breaks up - that is, how fathers after a divorce continue or desist in their provider role, and what influence this dimension has on the relationship they maintain with their children.

3 The author conducted this study in 2004-2005 as part of her doctoral project 'Parenthood after Divorce in the Czech Republic'. 


\section{Research methodology}

The methodology used in this research analysis in this paper is based on grounded theory [Glaser 1978; Strauss and Corbin 1999], and is particularly inspired by the constructivist version of grounded theory propounded, for example, by Kathy Charmaz [2003] and Jean-Claude Kaufmann [2001]. The assumption in this methodology is that the reality that I discover arises out of an interpretative process and from its temporal and cultural circumstances. Thus it is not just a matter of discerning a single objective reality of post-divorce fatherhood but rather understanding the ways in which the subjects under analysis construct and interpret their own subjective reality.

The basic research question is how fatherhood is perceived and understood by men who, after separating from their partner, do not have custody of the children, no longer share a home with them or have day-to-day ritualised contact with them, and cease to live within the family they helped found. The aim is to grasp how these fathers reconstruct and maintain their paternal and male identity, how they accommodate and create their own paternal role, how they interpret the situation they find themselves in, and what kind of rationalising strategies they elect in this new situation.

The target group in the research was men who had divorced the mother of their child or children in the period between 1989 and $2000^{4}$ and whose children were no older than thirteen at the time of the divorce. This meets the condition that there be a consistent, global socio-economic experience in the entire sample population and at the same time ensures that the events that respondents refer to are not too far back in the past. The age of the child at the time of divorce is capped so that the respondents were at least for some time required to be in the situation of a divorced father of child who had not yet reached puberty, which has specific implications for the construction of the paternal identity and role. It is with smaller children that the question of everyday care arises, as it can be assumed that they are not yet self-sufficient in life and require greater attention and concern.

The sample includes men between the ages of 25 and 52, with children between the ages of 3 months and 23 years. Roughly one-half of the respondents have university-level education, and the remainder have secondary education or vocational training in some profession. The structure of education is to some degree replicated in the economic standing of the respondents, but does not necessarily correspond in all cases. The majority of respondents have the standard, courtordered amount of contact with their children, which is every second weekend and a part of the summer holiday term. Fourteen of the respondents adhere to this courtordered routine, five fathers see their children less often owing to the fact that their

\footnotetext{
${ }_{4}$ The major part of the sample population was selected using the snowball method and contacted by telephone with a request for an interview; seven respondents were selected from a database at a psychological counselling centre and were contacted by post. Sample saturation was used to set the number of interviews, and a total of 35 interviews were conducted.
} 
children are older and they or their children have little free time, and two have less frequent contact because their former spouses at times prevent them from seeing the children. Four respondents opt for more frequent but shorter, irregular contacts, where the children do not stay with them overnight. Five fathers in the sample maintain more frequent than average contact with their children: two of them have joint custody of the children, two spend roughly a third of their time with the children, and one father has sole custody of one of his children. Finally, five respondents have no or only rare contact with their children. ${ }^{5}$

A constructivist version of grounded theory [Charmaz 2003] was used to analyse the data, based on the assumption that no 'epistemological rupture' exists between the everyday knowledge of respondents and the theoretical knowledge of social scientists. The methodology's theoretical assumption is that no recognisable, objective social reality exists, and instead what we have are numerous subjective social realities shared by various groups of actors [Charmaz 2003; Schwandt 2003; Potter 1996]. Using this approach it is possible to reveal how a given group of men see and interpret their situation, what significance they assign to the experiences they encounter, their own actions and the actions of others, and how their interpretations subsequently influence the direction of their other actions. Divorced fathers have their own subjective social reality, which is obviously just one of the many social realities that together make up and compete with each other in the space of post-divorce parenthood. The biggest limitation to this method of analysis is that it does not encompass respondents who refuse to speak about their situation, and that is likely most often the case of divorced fathers who maintain no or only irregular contact with their children.

\section{The provider as one of the main repertoires of fatherhood}

Despite all the changes fatherhood has undergone in recent decades, the relationship of the father to his employment has not changed in any fundamental way [Castelain Meunier 2002; Townsend 2002]. All the interviews conducted with the respondents in the sample revealed that the dimension of provider is still a key factor in male identity. Even if they do not actually define themselves in the first place as the provider in the family, they all do feel the need to define themselves in some way in relation to this norm. All the respondents are aware of the general expectation that the father should financially provide for and support the family. This norm is present everywhere, but fathers differ in terms of how much they accept and behave in accordance with it.

Considering that the wives of all the respondents had had paid employment at least at some phase, the household model of provider/housewife (in which the man only provides materially for the family and the woman only looks after the chil-

\footnotetext{
5 The names used in the article are not the respondents' real names.
} 
dren and the household) was never permanently applied in any of the cases. Nonetheless, the significance of the economic activity of the men and the women in these families, as in the population as a whole, differed. Even though a woman's income is essential to maintaining a satisfactory standard of living in the family, it is perceived as secondary, while the man is primarily responsible for the household's material security. In the man's case paid employment is taken as a given and he is not required to deal with the issues of reconciling work and family commitments. He invests more into his professional career than the woman does, and his income is usually higher than that of a woman with the same level of education. Unlike women, his career is not interrupted for family reasons. The periods of maternity and parental leave are a time when the family usually relies on one income, and with just one exception in the sample it was the man's income. The relatively long period of parental leave in the Czech Republic (from two to six years) gives rise to a situation where the family functions for a while according to the 'traditional' model, in which the father is the sole provider.

The dimension of provider does not just involve the financial contribution from paid work but also other material provisions for the children. In the Czech Republic this refers mainly to home improvements, an activity that is perceived as part of the father's investment in his family and children and that the father views as equal in value to the time spent personally with his children and to his paid professional work. One respondent, Oldřich (an entrepreneur; 2 sons, ages 17 and 14), used to spend time on home improvements in the family flat, which after his divorce his wife and children continued to live in, and he perceived that time as more than just a material contribution for his children, but also as time spent in their company, which further confirmed him in his position as a father: 'Because I contributed a lot to improving the flat in Sojčák, ... I spent a lot of time there'. Conversely, Richard (an automotive service employee; one daughter, age 10) viewed work on home improvements as a way of compensating for his absence from paid employment: 'I was unemployed for around five months in '92, so I worked on the flat'.

Even though while engaged in economic activity the father is not present in the household and in the company of his children, his employment is part of his paternal role and identity. Men regard their professional time (before divorce) as time spent as a father - work for them is one way of looking after their family and children.

'But I really looked forward to having a child. That's for sure. I looked forward to being a family, and I went to work and earned money to provide for us.' (Kamil, employee of an NGO; one son, age 14)

'I'll conclude it with this, I'm going to work so that some day the firm benefits the kids, and so that here, after I'm gone, let's say, there'll be something to remember me by.' (Vít, company director; two daughters, ages 21 and 17, one son, age 5) 


\section{Divorce and the provider repertoire}

What kinds of changes does divorce bring about in the attitudes of fathers toward the provider repertoire? How much do they remain the family provider after the divorce - if they are no longer the provider do they see themselves at least as the provider for their children, who are not in their custody and do not share their household?

In reality it may be said that this involves a dimension of fatherhood that expresses itself noticeably after divorce, either negatively or positively. All the respondents expressed a feeling that after the divorce they were expected to continue in the role of provider but nothing more, and that in the other dimensions they were shut out of the family (according to Daniel (translator; one daughter, age 6) the main expectations from a father after divorce can be easily summed up as 'shut up and $\left.p a y^{\prime}\right)$. The differences occur in how much men agree and identify with this expectation.

After a divorce relationships that to that time had functioned in some manner within the 'communist community' of the family are suddenly calculated in explicitly financial terms [see Arendell 1986; 1995]. The main change in the provider repertoire is probably that after the divorce the married couple, and thus also the parental couple, ceases to exist as a unit, and this becomes most evident in the division of the previously joint family budget into two parts. The division of labour in the family, where physically looking after the household means in theory the same contribution to the family as financial security and vice versa, is challenged. The mother no longer represents the parental couple, that is, the father, to the child in the father's absence. The father's financial contribution ceases to be for the child a visible symbol of the father's involvement. If the mother refuses to mediate the father's role by speaking of his work and financial contribution, his role as provider can become completely invisible.

\section{The two levels of financial support}

After divorce fathers are most often able to perform the provider repertoire of their paternal role on two basic levels. The first is by paying a court-ordered sum of child support, and the second is what the father gives the mother or child voluntarily in addition to that [see also Cohen 1993; Municio-Larsson, Pujol Algans 2002]. Although the first level is actually defined as mandatory, both involve a certain kind of negotiation, whether between the actors involved or in the minds of the respondents. The majority of respondents nonetheless accept the fact that it is necessary to pay child support - even though some of them consider the amount too high, or view it as unfair given the wife's income or owing to the circumstances of the divorce. Despite this initial blanket acceptance of the obligation to pay child support after divorce, many of the respondents eventually admitted that there are situations where child support should not have to be paid, for example, if a woman leaves her 
husband for a richer man, or when the mother does not allow the father any contact with the child. In this case the mother is not fulfilling her obligations to the father, and therefore the father need not fulfil his obligations to the mother.

Evident from the above is the basic paradox of the provider repertoire as the building block of the paternal role: before divorce the father sees himself as the 'family provider', providing money for the entire household, not just the children, and investment into the household is essentially also an investment in the children. After the divorce the family as a unit dissolves, and the father can no longer be the 'family provider'. Theoretically he should remain the provider for his children, but they now belong to the household of his former wife, with whom he is in some more or less serious conflict. The majority of fathers do not distinguish between the personal needs of their former wife, the needs of the household as a whole, and the needs of their children.

Fathers take a more creative approach to contributions beyond the margins of mandatory child-support payments. They may use the additional resources to negotiate with the wife or even the child. If the wife does not abide by the established terms (for example, she refuses to allow the father contact with the child), she does not receive any additional money or gifts. As Jan, one respondent (journalist, one daughter, age 5) said: As we agreed, as I can now, so I pay the child support. And when the relationship was working and I could go there, which wasn't properly understood, then I helped her materially more than I had to. Buying clothes and stuff like that. Conversely, the mothers use their control over the time spent with the child to negotiate additional financial support - when they're in need, they allow the father contact with the child, which they may previously have blocked, in order to obtain additional money.

Unlike child support, the father has some control over the additional contributions he makes. He can give his contributions directly to the child, so that the child is aware of them, and he is able to decide how the money will be used. Courtordered child support is often interpreted as a contribution to the wife, while additional contributions are viewed as being directly for the child. Jan's view was: 'It's not that I'm taking revenge on the child, definitely not. It's just, I give the money to her and not to the child, and I don't know what she does with it'.

The fathers' preference for direct and voluntary material contributions to cover their children's needs is connected with the very nature of fulfilling the provider dimension of the paternal role. The provider dimension is of key importance for many of the respondents, but when they contribute in the form of child support payments they may be invisible to the child [Seltzer, Schaeffer and Charng 1989]. By buying something with the child or giving the child money the provider dimension is exercised and visible in practical terms. 


\section{How fathers relate to the provider repertoire}

Although the provider repertoire is in some way a part of the paternal role of all the respondents in the sample, and this traditional norm of fatherhood still significantly influences the construction of the paternal identity of Czech fathers, differences appear in the way in which the fathers, during the interviews, defined themselves in relation to this norm, and in the way in which they interpreted the provider repertoire in specific terms. Not all of them give clear priority to this dimension of fatherhood, and not all of them consider fulfilling the obligation of supporting the family as sufficient for the fulfilment of their role as a father.

It was possible to distinguish three model approaches that surfaced in the responses of the divorced fathers in the interview sample with regard to how they relate, in their attitudes and practices, to the norm 'the father must provide for the family'. These approaches may of course apply to fathers in general and not just to divorced fathers. These three approaches represent three ways in which the respondents currently perform their repertoire as provider, and as such form part of their individual paternal role and also identity. Those different approaches than reflect in the behaviour of father as a provider before divorce, and also in the ways in which fathers relate to the provider repertoire after divorce. ${ }^{6}$

These three model approaches to the norm of father as provider were identified with the use of grounded theory in coding and classification. They represent a certain analytical simplification of social reality, but they nonetheless best reflect the areas where the respondents most coincided or differed, and it was possible to classify each respondent in one of the three groups. It is important to point out that not all respondents necessarily exhibited a fixed tendency to belong to one single model approach, and during a respondent's life course the model they belonged to changed in some cases, particularly in relation to the specific situation of the Czech Republic and the transition process that society has been going through.

\section{Group A: The 'full' providers}

The first group consists of fathers who accept this norm without reservations - they believe that the father is primarily responsible for financially providing for the family, and for them being a father means fulfilling this provider role. Ten men from the

\footnotetext{
${ }^{6}$ Men's willingness to contribute after divorce to covering the material needs of their children, and thus their continuation in the provider repertoire, depends on numerous external circumstances. Of importance is who it was that initiated the divorce, whose 'fault' it was, and why the divorce had to happen. Another factor is the question of whether the father regularly sees his children and whether his former wife allows him to see them. But just as they were before the divorce, of fundamental significance here are the father's general ideas about the division of gender roles in the family and about the provider repertoire as part of the paternal role.
} 
sample could be classified in this group. Some of them responded that they are against any questioning of this role and asserted its validity, and they felt threatened by and rejected the changes that are occurring in society: 'My feeling is that it's been established for several centuries that the man takes care of the income and making sure the family survives and the woman takes care of making sure everything comes together, and I think it'd be pretty difficult to change that.' (Oto, accountant; one son, age 24, one daughter, age 20) Stressing the traditional norm of fatherhood goes hand in hand with an emphasis on the traditional norms of motherhood, where the mother is designated as responsible for the household and the children.

The fathers in this group, before they divorced, genuinely endeavoured to fully support their family and did not share this responsibility with their wives. Some of them exemplified this approach even before the changes that began to occur in society in 1989, and the economic transition only opened up new opportunities with which to fulfil their provider repertoire. In order to manage this they, for example, would hold two jobs or they began their own business - they invested the maximum in their professional life to provide for the family. This was Richard's experience (automotive service employee; one daughter, age 10): 'I held, say, two or three jobs, just to make up a bit at the other end, you know.' For this group of fathers providing for the family meant bringing the maximum amount of money into the family budget. The more money, the more satisfied they were with the image of themselves as a father. But their work commitments left them little time or energy for other activities associated with fatherhood, as Jan reports (journalist; one daughter, age 5): 'It's a neverending cycle, going to work, reconstructing the flat, so there was no time. Then there was the flat, but I was going to work all the time because there was always something that needed paying for, and somehow it had to be done.' Here the repertoire of provider is the most fundamental component in the paternal role and paternal identity.

In return the men in this group demand that this division be respected and recognised also by their wives. They are convinced that as long as they fulfil their role as provider they have fulfilled their duty as father, and the wife has no right to demand more of them. If the woman is not satisfied with the man's definition of the paternal role, conflict and misunderstandings ensue, as was the case of Jan (journalist; one daughter, age 5): 'In actuality I can't understand it, I mean I provided us with a flat, I got work, I don't understand where all that hate comes from.' According to Ivan (bank employee; two daughters, ages 5 and 9) the woman should respect and appreciate her husband for his economic contribution and not demand more of him:

'There's a huge difference now.... She acknowledges me as being capable of making money, she knows what it involves when I have to make money, because I'm sitting up to three or four in the morning several nights and I have to do it, we have deadlines, but it's for the money.... She doesn't mind at all if I come exhausted from work and just sit down and need to rest, she's not lazy, she cleans the whole place and she doesn't need my help. It's a different approach; it's respect for the other person.' 
Within this group of men whose role as father draws primarily on the repertoire of family provider it is possible to detect differences in their background experience. From the perspective of the Czech Republic's specific situation as a country in the process of social and economic transition, a significant part of this group are men who reduced their paternal role to the repertoire of provider after the onset of capitalism, and the way in which they interpret the paternal role was facilitated by the change in the political and economic system. These men now define themselves mainly in professional terms. After the revolution they threw themselves into making money, and they managed to become successful. Usually they are independent businessmen, managers, or independent professionals in lucrative fields. They have little free time and they are capable of more or less supporting their family alone, so they put stress on the traditional norm of fatherhood. What is interesting is that these are often men who under the communist regime, before they were fully engaged in the professional sphere, did not ascribe the role of supporting the family any major significance. They originally belonged to group B and were providers only at the representative level, but following the change in circumstances in society and the positive change in their own professional life their approach to the father-provider repertoire also changed, and they began to conform with group A. Their position is not fixed by clear and firm convictions about the primary significance of the traditional norm for the paternal role and about the traditional gender-based division of labour, but by circumstances, and these of course correspond to the notion of fatherhood rooted in tradition.

Before divorce the men in this group focused their paternal role on the provider repertoire and provided for the economic needs of the family without any significant contribution from their partner. After divorce, they continue to acknowledge the provider/caregiver distinction, and they are willing to contribute more than the wife to the economic needs of their children, just as before the divorce. Many of them moreover continue to feel an obligation to support not only their children but also their former wife as compensation for the fact that she personally takes care of and is raising the children. After divorce not only should the mother not have to cover the costs of raising the children, but because she is caring for the children she has the right to support for herself. This point of view was expressed by Vít (company director; two daughters, ages 21 and 17, one son, age 5), a successful businessman with an above-average level of income: 'She's someone with a normal wage, so she wouldn't be able to afford much. So you have to take care of that. And the girls live with her. One still lives there all the time, the other just on weekends now. But I'm committed to the kids and to my wife for giving me the kids, too.' Similarly, Josef (university lecturer) also does not question the obligation to support his now seventeen-year-old daughter by making a larger contribution than his former wife, given that even before the divorce the division of roles in the family was similar: 'I think that I contribute more financially, but that's not a problem for me, because basically, even in the marriage, I was making the money and she was at home.'

Men who accept their role as the sole provider for their children are usually men with higher incomes (not all men with higher incomes however share this 
view). They find their paternal identity in the fact that they economically provide the child with something that the mother cannot - additional material resources, private schools, expensive vacations, and travel. They are moreover aware that the expenses associated with raising children are much higher that the amount of child support set by the court, and they tend also to contribute in other, supplementary ways, but ways that they choose and control themselves.

\section{Group B: fathers who are providers on the representative level}

The second group is made up of fathers who accept the traditional norm but are also aware of the new demands that compete with the old and introduce certain paradoxes. The majority of the sample, i.e. 18 respondents, is in this group. The norm dictating that the father is above all the provider in the family is not as obvious and unequivocal in this group. These internal conflicts are reflected in the responses of some of the men interviewed, where we were direct witnesses to a process in which they became aware of the pluralist nature of fatherhood: 'In some way it's sort of normal that the dad should support the family. Normal? Well, I guess it isn't today, but... he probably should in some way provide for the family.' (Radek, factory worker; one daughter, age 9) In this group the father's obligation to support the family is still the main dimension of fatherhood; it is an inseparable and unquestionable part of the paternal role. However, the fathers in this group are still aware that in addition to this norm there are also other obligations and demands that a father should attend to and that providing for the family alone is not enough, even though it continues to be the father's primary function. In addition, these men realise that attending to all the responsibilities associated with fatherhood, both the old and the new, is very demanding, and that these demands sometimes even seem incompatible. Frankly put: 'You've gotta work like a nut to make money and then you're never home.' (Filip, taxi driver; two daughters, ages 13 and 7)

The men in this group see themselves as providers, but a deeper investigation reveals that in reality their families relied on the income of both partners in the couple, so the man is the provider only on a representative level. While the men emphasise the role of the man and the father as that of the provider, and also see themselves as such, their income is insufficient to support the family alone and is often no higher than that of their wife. Even though in practical terms they are not actually providing for the family, at least not exclusively, they perceive the provision of its material security as their main paternal responsibility. The fact that the man has a child automatically means that he must take care of the child's material needs - for this group of men this responsibility is not open to question or discussion. 'But I don't have a problem with having to support my kid.' (Miroslav, driver; one daughter, age 10) For them, 'supporting' the family does not mean bringing in the maximum amount of money possible; it means 'providing' for the child, and that signifies different things to different men. It does not necessarily mean bringing home the most money and devoting all available time to making money, but rather involves ensuring an 
acceptable standard of living, as subjectively determined by the fathers. This was Antonín's view (warehouse employee, one daughter, age 7): 'Naturally, to provide for the child's well being. That's important. But I wouldn't say that I'd necessarily have to make millions.' There is enough room left open to these men to draw on other repertoires, and fatherhood is not restricted to just supporting the family. It remains the key paternal activity, but mainly at the representative level; in practical terms it is just one of a set of parental roles that both the child's father and mother devote themselves to.

Before separating from their partners, the provider repertoire was for this group of fathers a very important element in the composition of their version of the paternal role, but only in terms of the man being primarily responsible for the economic situation of the family. After divorce, however, the family as a unit breaks up, and the man, according to his understanding of things, ceases to be responsible for the material welfare of his children's household. Even though at the general level these men usually continue to claim that the father is supposed to be the main provider, in practical terms they view their contribution after divorce as just that, a contribution - the wife must financially contribute and must do so by providing for at least half of all the material needs of the children. The financial contribution the fathers make to the children should in their view be used exclusively for the child and not for the needs of the wife or her new family. After divorce the father-provider and mother-caregiver distinction ceases to apply. Personally looking after the children and the household and materially providing for the children and the household cease to be mutually commutable and of equal value. This means that the mother's personal care for the children is not compensated with money, as is the case in the two-parent family.

However, as long as they live in a two-parent family the fathers do not usually have an exact idea of how much they invest into raising their children and into their family. Men usually have a distorted idea of what a child actually needs and how much it costs. Consequently the sum they must pay seems too high, and they are convinced that the former wife is using the money for herself. In a two-parent family the social, economic, and cultural capital of its members is calculated, and investments into one area increase the benefits for everyone. Once the father no longer shares a household with his children and their mother, there are no subjective returns to him through an increase in his own capital from whatever he invests.

Men in this group nonetheless accept the basic responsibility for the material welfare of their children - as Miroslav said (driver; one daughter, age 10): 'Once I have kids, then I have to take care of them'. Another respondent, Antonín (warehouse employee; one daughter, age 7) summed up his approach similarly: 'But on the other hand, I say to myself, you've got to pay. It's not that the kid was a mistake or anything, but once you've got a kid, then you should pay something.' But like before the divorce, for these men 'supporting' the family does not mean bringing in the most money. Instead it means 'material security', and that signifies different things to different men. 


\section{Group C: fathers who refuse to be providers}

For the men in both groups described above fatherhood is a firm component of their male identity, and being a father means first of all being the family provider. For those seven men other dimensions of fatherhood are optional. But there were several men in the sample who questioned the requirement that the father is mainly the provider and disputed the traditional norm of fatherhood. These men accorded greater importance to other dimensions of fatherhood that do not put them at a distance from their children and do not force them to spend long hours away from home. However, it is necessary to make a distinction between those fathers who questioned this norm (at least according to their responses) even before their divorce, and those who began questioning it after their divorce.

Some of the respondents, in their own words, rejected the obligation to support the family as their primarily paternal role even before they divorced, and they ascribed other dimensions of fatherhood with equal or greater importance and demanded from their wife that she equally contribute to materially providing for the family. According to Daniel (translator; one daughter, age 6) one of the reasons that led to his divorce was the fact that his wife refused to contribute to the family budget and assumed that he would be the sole provider in the family: 'She had this neat idea that she wasn't going to contribute anything to the household out of her pay. That she was going to make money, and she'd keep that for herself. These fathers reject the traditional division of roles in which the mother takes care of the children and the father is the provider, and do so even at the representative level. They do not want to be reduced as fathers to just 'the one that pays for things'. Some of these men, for example, Tomáš (painter; 2 daughters, age 5), spent some or all of the period of parental leave with their children, while the wife provided economically for the family. Vladimír (insurance agent) looked after his small son when his wife decided to work abroad, where she had a much better opportunity to earn money. For these men the repertoire of provider is not the most significant component in their paternal identity. But divorce presented them with an entirely new situation.

This group of fathers does not include the provider repertoire in their paternal role and contests the obligation of financially providing for their family as the first and foremost responsibility of the father. These men moreover have the feeling that after divorce this is the only dimension of fatherhood that is expected of them, and given that even before their divorce it was not in their view a dimension of significance or one they accepted, they find themselves in serious conflict with the expectations of society. These fathers are among those who most often question the obligation to pay the court-ordered amount of child support or just do not pay it at all. 


\section{Conclusion}

The changes that in recent decades the normative model of fatherhood has undergone in industrialised countries are increasing the plurality of demands and norms associated with fatherhood and also the plurality of ways in which fathers can be fathers - how they can interpret and construct their own version of the paternal role. The dimension of father as provider is part of the traditional normative sphere of fatherhood and in the social imagination of contemporary Czech society it continues to be of fundamental importance. All the respondents in the study feel a strong amount of social pressure to fulfil this function, and if a couple with children splits up it is generally assumed that this dimension of fatherhood particularly should be upheld, even if the others vanish. In this sense the commitment to provide for one's children represents an even stronger obligation associated with the role of father when the nature and content of social roles in general and the paternal role in particular are changing; the social role is becoming dependent on individual choice and is no longer defined in terms of a clear set of obligations and expectations tied to a certain position in society.

However, men do not accept the norm of provider across the board and without reservations. In this qualitative study of fatherhood after divorce in the Czech Republic it was possible to distinguish three ways in which fathers relate to the repertoire of provider as one and evidently the most important dimension of the paternal role. The respondents in the most numerous group B see themselves as providers, but a deeper investigation reveals that the family before the separation in reality depended on the income of both parents, so the man is only the provider on the representative level. After divorce, the men assume that the mother will contribute to providing for the material needs of the children and they view their financial contribution as really just a contribution. Another group of men (group C) question or explicitly reject this norm and fulfil themselves through other repertoires of fatherhood. After divorce they worry about their paternal role being reduced to the single dimension of provider. For this group of men the reconstruction of the paternal role is very difficult, especially if they find themselves in the typical and, in the Czech Republic, most common custody arrangement after a divorce, which allows only limited personal contact between the father and child, while the father's responsibilities as provider are preserved. In this regard, those fathers who accept the provider norm of fatherhood (like those in group A), and for whom it is the main dimension of the paternal role, find themselves in an easier position. Separation from their children does not require that they make any fundamental changes to the way in which they perform the role of father, they are able to continue in the provider repertoire, and their absence from the household does not signify any major change in behaviour. On the other hand, these fathers are exposed to the threat of their support for the child being rendered invisible if the child is not made sufficiently aware, either through joint activities or through the mother, of how the father contributes as a provider.

Experiences in the Czech Republic and throughout the world indicate that 
child support payments, as set out in court or a divorce agreement, are usually not paid regularly by fathers and sometimes not even at all, or they are paid only for a period after the divorce. In the interviews the respondents gave various instances where they felt it legitimate not to pay child support or to limit their financial contribution, or indicated what they felt to be the biggest problem about the obligation to provide material support for children they no longer share a household with after divorce. But the reasons for abandoning the provider duty vary between the groups because they are connected with the attitude of men towards the traditional norm of the father as family provider. The men from the largest group B (the fathers who are providers at the representative level) cease to perceive themselves as the 'family provider' when the parents as a couple and the family cease to exist as a unit. Theoretically they should continue to be the provider for the children, but the children now belong to the household of their former wife. The majority of those men do not make a distinction between the personal needs of the former wife, the needs of her household as a whole, and the needs of the children. Many of them believe that the obligation to continue in the role of provider should be derived from the reasons for the divorce and take into account which spouse's 'fault' it was. Another problem is the loss of control over their own income that some men sense after divorce. They are unable to provide or control what the money will be spent on. Investment in the children, which they formerly perceived as investment in the family, and by extension in themselves, loses its original significance. For the fathers in group $\mathrm{C}$, who reject the provider norm, there may be a reduction in the willingness to financially support the children when original agreements on contact and visits with the children are not respected by the former wife or when they consider that they are not allowed a sufficient amount of time to spend with their children. They refuse to reduce fatherhood to the provider dimension and they prefer to draw on other repertoires or to not be fathers at all. With regard to group $\mathrm{A}$, the fathers who tended to be 'full' providers before the separation, a significant factor is that after divorce the father's financial support for the child ceases to be evident and perceptible because it is no longer mediated through the mother or is sometimes even concealed from the child. As a result, for the father the act of paying child support loses its significance as paternal behaviour, and it is not perceived as a validation of his paternal identity. His motivation to provide this contribution thus dissipates as his contribution ceases to be perceptible or visible.

The dimension of provider is a dimension of fatherhood that is subject to the normative impulses of the social environment and society's institutions and exhibits strong continuity after the divorce of a couple. Nonetheless, men approach this dimension creatively and reinterpret it in various ways and in accordance with their own needs. The unwillingness to pay their financial contribution and the reasons that lead to such a situation indicate that divorced fathers have an unclear relationship to this norm and its acceptance does not necessarily imply its subsequent fulfilment in practice. 
RADKA DUDOVÁ is a researcher in the Gender E Sociology Department at the Institute of Sociology, Academy of Sciences of the Czech Republic, and a student of sociology in the doctoral programme at the Faculty of Philosophy and Arts of Charles University and at Université Paris 5. She specialises in the study of changes in the contemporary family and private life, the rise of new types of family cohabitation, and parenthood after divorce.

\section{References}

Arendell T. 1986. Mothers and Divorce: Legal, Economic, and Social Dilemmas. Berkley: University of California Press.

Arendell T. 1995. Fathers and Divorce. Thousand Oaks: Sage.

Baker M. 1997. 'Entre la pain et les soins: les pères et la loi canadienne sur le divorce.' Lien social et Politiques - RIAC 37: 63-73.

Bowmann M. E., Ahrons C. 1985. 'Impact of Legal Custody Status on Fathers' Parenting Postdivorce.' Journal of Marriage and the Family 47: 481-488.

Castelain Meunier C. 2002. La place des hommes et métamorphoses de la famille. Paris, PUF.

Cohen T.F. 1993. 'What Do Fathers Provide?' Pp. 1-21 in Men, Work and Family, edited by J.C. Hood. London: Sage.

Glaser B. G. 1978. Theoretical Sensitivity. Mill Valley: Sociology Press.

Hašková H. 2003. 'Partnerství v rodině.' (Partnership in the Family) Pp. 39-64 in Rovné př́ležitosti mužů a žen při slad’ování práce a rodiny? Prague: SOU AV CR.

Charmaz K. 2003. 'Grounded Theory. Objectivist and Constructivist Methods.' Pp. 249-285 in Strategies of Qualitative Inquiry, edited by N.K. Denzin and Y.S. Lincoln. London: Sage.

Ihinger-Tallman M., K. Pasley and C. Buehler. 1995. 'Developing a Middle-Range Theory of Father Involvement Postdivorce.' Pp. 57-77 in Fatherhood. Contemporary Theory, Research and Social Policy, edited by W. Marsiglio. Thousand Oaks: Sage.

Kaufmann, J.-C. 2001. L'entretien compréhensif. Paris: Nathan.

Meyer D. R. and J. Bartfeld. 1996. 'Compliance with Child Support Orders in Divorce Cases.' Journal of Marriage and the Family 58: 201-211.

Modak M. and C. Palazzo. 2002. Les pères se mettent en quatre! Laussane: EESP.

Municio-Larsson I. And C. Pujol Algans. 2002. 'Making Sense of Fatherhood: The Nonpayment of Child Support in Spain.' Pp. 191-212 in Making Men into Fathers, edited by B. Hobson. Cambridge: Cambridge University Press.

Naše společnost 2003. (Our Society 2003) Prague: SOÚ AV ČR. Research data.

Potter, J. 1996. Representing Reality: Discourse, Rhetoric and Social Construction. London: Sage.

Radimská R. 2003. 'Rozvedené a svobodné matky v České republice.' (Divorced and Single Mothers in the Czech Republic) Gender, rovné př́ležitosti, výzkum. 1-2: 11-14.

Seltzer J.A., N.C. Schaeffer and H. Charng. 1989. 'Family Ties after Divorce: The Relation between Visiting and Paying Child Support.' Journal of Marriage and the Family 51 (4): 1013-1031.

Schwandt, T.A. 2003. 'Three Epistemological Stances for Qualitative Inquiry.' Pp. 292-331 in Strategies of Qualitative Inquiry, edited by N.K. Denzin and Y.S. Lincoln. London: Sage.

Singly F. de 2000. Le soi, le couple et la famille. Paris: Nathan.

Singly, F. de 2003. Les uns avec les autres. Paris: Armand Colin.

Strauss A., Corbinová J. 1999. Základy kvalitationího výzkumu. (The Basics of Qualitative Research) Boskovice: Albert.

Townsend N. W. 2002. The Package Deal. Marriage, Work and Fatherhood in Men's Lives. Philadelphia: Temple University Press.

Velký sociologický slovnik 1996. (Unabridged Dictionary of Sociology) Prague: Karolinum. 